\title{
BITTERLING POPULATIONS IN THE SIGHIŞOARA-TÂRNAVA MARE NATURA 2000 SITE - A SUPPORT SYSTEM FOR MANAGEMENT DECISIONS
}

\author{
Angela, CURTEAN-BĂNĂDUC ${ }^{1}$, Ioana-Cristina, CISMAȘ $^{2}$ and Doru, BĂNĂDUC ${ }^{3}$ \\ 1"Lucian Blaga" University of Sibiu, Sibiu, Romania, angela.banaduc@ulbsibiu.ro \\ 2"Lucian Blaga" University of Sibiu, Sibiu, Romania, cristha_83@yahoo.com \\ 3"Lucian Blaga" University of Sibiu, Sibiu, Romania, ad.banaduc@yahoo.com
}

\begin{abstract}
The predominant threats to the Bitterling populations in the Sighişoara-Târnava Mare Natura 2000 site are the hydro technical modifications of the river channels, organic contamination and illegal fishing. ADONIS:CE is applied commonly for business processes modelling, however, in this study case was applied in an ecology/biology sphere of interest. The authors acquired a Bitterling model which contained all of the identified habitat species' necessities, the specific indicators that give good preservation status and the present pressures and threats. The keeping of the riverbed morphodynamics is especially necessary - the meanders existence is significant for the aquatic mollusc species which are existing in the inner $U$ shape sectors of the lotic systems. The sectors, where the sand and mud are relatively fixed, give appropriate habitats for molluscs which is valuable for the reproduction of Bitterling. The preserving of the present water oxygenation and regime of liquid flows, and the prevention of the sediments deposition rate in the aquatic habitats are needed too for the molluscs' existence. The sediments exploitation in these lotic systems should be realised in relation with the natural rate of renewal and at sites at a distance over five $\mathrm{km}$ between them.
\end{abstract}

KEY WORDS: Bitterling, pressures, threats, aquatic habitats necessities, modelling management processes.

\section{INTRODUCTION}

All the EU countries have to implement a rigorous conservation of the species of interest recorded in the Habitats Directive (Annex 2) and not admit the decline of ecological quality determined by anthropic activities (*, 1992).

The Romanian Natura 2000 network sites, containing also those designated for fish species' conservation, were suggested for protection of their ecological quality. The suggestions were based on special selected criteria: excellently preserved, permanent and vigorous fish populations, characteristic habitats, proper geographical location, and approximately small anthropic effects. Ordinarily, there are some significant methods, based on how the Natura 2000 network strategy can enhance the EU members' nature conservation: institutional competency building, the enlargement and multiplication of the natural areas, promoting awareness, and the application of proper management plans for the areas' value from the conservation point of view, (Bănăduc, 2001, 2007a, 2008a, b, 2010, 2011, Bănăduc et. al., 2012, Curtean-Bănăduc and Bănăduc, 2008).

European bitterling/Rhodeus amarus (Bloch, 1782) is a fish species of community interest. These fish live in fresh and slow flowing or standing water habitats, by preference in the middle of macrophytic type vegetation, over sandy and/or muddy substrata. This fish are sexually mature at one year and at a standard length of $30-35 \mathrm{~mm}$. The breeding takes place from April to August and it is strictly linked by Unio and/or Anodonta freshwater mussels, (Bănărescu 1964; Bănărescu and Bănăduc,
2007). During the breeding period, male individuals have shining nuptial colors and safeguard a small space near the mussel, as long as the female individuals use ovipositors to drop roes through the exhalant siphon onto the gills. Males fecundate the roes by releasing sperm into the mussels' inhalant siphon which transports the sperm to the roes (Smith et al., 2004). Embryos stay in the mussel for around one month up to swimming ability (Aldridge, 1999). This fish feeds chiefly on diatoms, filamentous green algae, vegetal detritus, and sometimes insect larvae and crustaceans. It has a short-living period; the maximum recorded age is five years. Males generally are much numerous than the females in the population, particularly on the breeding grounds (Bănărescu, 1964, Holcik, 1999, Bănărescu and Bănăduc, 2007). This fish is sensitive to water temperature changes, water pollution, and degradation of its characteristic habitat (Holcik 1999).

The range of the Bitterling becomes more fragmented in Romania, notably in the last half of the century, due to the anthropogenic activities effects which vary from one watershed/watershed section to another and alike in some Natura 2000 sites and other types of protected areas (Ardelean and Wilhelm, 2007, Battes et al., 2003, 2005, 2009, Bănăduc, 2001, 2005, 2007, 2008a, b; Bănăduc and Curtean-Bănăduc, 2013, Bănăduc et al., 2013, Bănărescu, 1964, Bănărescu and Bănăduc, 2007b, Costiniuc and Gorgan, 2004, Costiniuc et al., 2006a, b; Florea and Contoman, 2014a, b, Oțel, 2007, Pintileasa et al., 2011, Pricope et al., 2001, Radu et al., 2008, Simalcsik et al., 2004, Telcean, 1999, 2010, Telcean and Bănărescu, 2002, Telcean and Cupșa, 2009a, b, Meșter et al., 2003, Momeu et al., 
2009, Năstase et al., 2008, Năvodaru, 2004, Năvodaru and Năstase, 2006, Ureche, 2008, Ureche et al., 2010, 2013, Vornicu et al., 2006).

The present structure of the fish associations, including Bitterling, in the Natura 2000 Site Sighişoara-Târnava Mare (ROSCI0227) reveal a declined number of individuals as an effect of constant human activities. The dispersion model of the fish associations and their density variability in this site reveal the correlated effect of lotic habitats quality in the Târnava Mare River watershed (Bănăduc 1999, 2000, 2001, 2005, CurteanBănăduc et al., 2007, Curtean-Bănăduc and Bănăduc 2001, 2004a, b, Curtean et al., 1999).

In generic circumstances in which aquatic ecosystems turn into an invaluable natural capital, the negative effect of the human activities will raise (Curtean-Bănăduc and Bănăduc 2012).

In this situation, no general management components can be used depending on a copy and paste technique in all relatively similar protected areas because different environments should be evaluated and monitored; and only from that time forward the optimum management elements should be upgraded and used for the specific identified conditions.

Currently, process modelling methods are being used to a greater extent to realise "the big picture" of dissimilar systems/actions of any sphere and also are a useful tool to facilitate comprehension of the process steps for optimum management. Modeling instruments are software products used by analysts, managers, or developers to create models of business organizations, evaluate models, and save data about models and provide three main functions. First, they provide evidence pertaining to present statuses. Second, they support and evaluate the impact of potential modifications. Lastly, they support plans to somehow modify the present state. As a consequence, they offer the capacity to design diverse categories of diagrams with helpful management components (Hall and Harmon, 2005).
The goals of this study are: to highlight the current state of Bitterling/Rhodeus amarus (Bloch, 1782) populations in the Natura 2000 site Sighişoara-Târnava Mare (ROSCI0227); to emphasize the present human activities' pressures and threats; to indicate management elements for the conservation and improvement of this species conservation with the support of management models based on particular necessities of the fish species and particular habitat indicators, as a decision support system for management.

\section{STUDY AREA AND METHODS}

ROSCI0227 is situated at $24^{\circ} 49^{\prime} 16^{\prime \prime}$ Longitude and $46^{\circ} 8^{\prime} 4$ " Latitude (315 to $829 \mathrm{~m}$ altitude, and $85,815 \mathrm{ha}$ ) is located in Mureş, Sibiu and Braşov counties, in the Continental biogeographic region. This protected area was established also for the protection of four fish species, belonging to the Habitats Directive (92/43/EEC), (Gobio kessleri Natura 2000 code 2511 (Romanogobio kesslerii), Barbus meridionalis code 1138, Sabanejewia aurata code 1146, and Gobio uranoscpus code 1122) (Natura 2000 Standard data form http://natura2000.mmediu.ro/upl//formulare/ROSCI0227\%20$\% 20 \mathrm{~F} . \mathrm{pdf})$.

The lotic systems sectors of the researched area where Bitterlings were sampled are presented in figure 1 .

The biological samples were collected from 2012 to 2014 with fishing nets, identified on site, and immediately released in habitats of origin.

Bitterling populations were monitored and their ecological status was evaluated in correlation to the human activities impact, in terms of pressures and threats.

The Bitterling species necessities and human pressures and threats were pinpointed and selected in the field based on their connection to the fish associations' status.

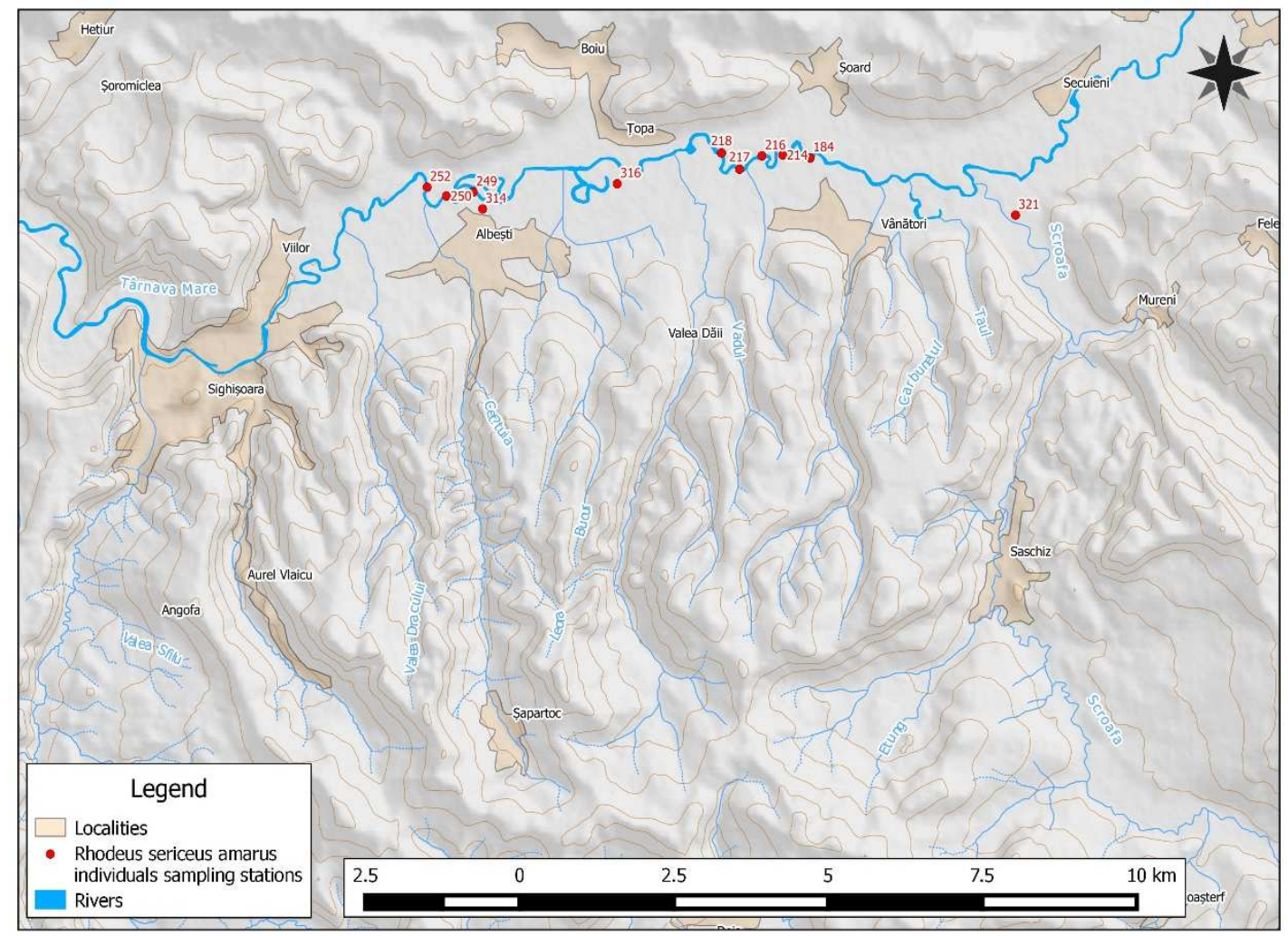

Figure 1. Rhodeus sericeus amarus individuals sampling stations: Scroafa Stream 321, Dăii Valley 316, Şapartoc River 314, and Târnava Mare River 252, 250, 249, 218, 217, 216, 214 and 184. 
In order to identify the management elements that have to be implemented to safeguard the species good conservation status and demonstrate the process, a management model was used. The model was ADONIS: CE, designed by Business Object Consulting. ADONIS: Community Edition is a tool (without charge and furnished by the BOC Group) which provides a very good entry point to professional Business Process Management. ADONIS: $\mathrm{CE}$ is an operative stand-alone version of ADONIS with some disadvantages in contrast to the commercial edition. BPMN (Business Process Model and Notation) is a worldwide standardized modelling language which can be used for processes demonstration. The needed processes can be modelled clearly, rapidly and seemingly, using consistent notation (**). Table 1 and Fig. 2 draw out and clearly state the key objects of ADONIS: CE (Hall and Harmon, 2005), used to model Bitterling management.

\section{RESULTS AND DISCUSSIONS}

\section{The assessment of Bitterling populations' state}

The population state of Bitterling in the Scroafa Stream in the sector 321 (Fig. 1) was low in conformity with: not fair distribution of individuals of different age classes, the size of population, dispersion area size, and the weight of individuals of the studied species in the structure of fish associations. The studied habitats, where the individuals of this species were found, were in a low state.

The Bitterling population state in the Dăii Valley in sector 316 (Fig. 1) was very good in conformity with: fair distribution of individuals of different age classes, the population size, dispersion area size, and the weight of individuals of the studied species in the structure of fish associations. The habitats, where the individuals of this species were found, were in a very good state.

The Bitterling population state in the Şapartoc Stream in the sector 314 (Fig. 1) was very good in conformity with: population size, balanced distribution of the individuals of age, fair distribution of individuals of different age classes, the population size, dispersion area size, and the weight of individuals of the studied species in the structure of fish associations. The habitats, where the individuals of this species were found, were in a very good state.

The Bitterling population state in the Târnava Mare River varies from good in the sectors 252, 250 and 249, to low in the sectors 218, 217, 216, 214 and 184 (Fig. 1), in relation with the different level of habitats' degradation.

\section{Identified present human preassures and threats}

In the Scroafa, Dăii, Şapartoc and Târnava lotic systems, some direct pressures on the studied species were identified: spoiling or major decline of natural habitats' characteristics of lotic systems because of regularization, poaching, including in the reproduction period (April-August), and habitat fragmentation/populations' isolation. Also, an indirect pressure was identified as organic pollution, which induced the dispersion of molluscs, on which the breeding of Bitterling rely upon. The pinpointed threats were: deficit of habitat features (the river bends and floodplain wetlands) due to some hydraulic type structures (embankments, accruals, ballast exploatation, water pollution, poaching.)

Bitterling specific needs
The adult studied fish individuals need slow flowing or stagnant freshwater areas of lotic systems, shallow water, and substrata with mud. The breeding strictly depends on the presence of these categories of habitats, and especially on the existence of mussels (Unio and Anodonta) because the females lay the roes in the paleal cavity of the mussel, where the initial growth takes place (Holcik 1999, Bănărescu and Bănăduc, 2007).

\section{Specific habitat indicators}

Based on this fish presence and abundance, habitat indicators can be thought-out: sectors with a water deepness smaller than $0.5 \mathrm{~m}(66 \%)$; percentage of muddy riverbeds (33-66\%); presence of dead tree branches and wetland areas next to the water courses (10-33\%); vegetal debris weight on the water courses substrate $(15 \%)$; weight of slow-water surface $(66 \%)$.

\section{Management measures}

The Bitterling conservation status can be enhanced in the study area if a few management elements will be applied and sustained, such as: preservation of the dead river branches and wetland areas neigh boring the rivers and streams; effective forbiddance of fishing/poaching in the reproduction period (April-August); restriction of intense and quasi-permanent poaching; preservation of the liquid flow, the channel current regime, and a regime of favourable oxygenation of the water, likewise the quantitative preservation and diverse increase of the contaminants in water with the goal to take care of the mollusk habitats, crucial for the breeding of the fish species of interest; preservation of the natural minor riverbed-meanders specific morphodynamics - meanders sectors presence is valuable for the mollusks' existence in the river bends where silt and sand are relatively more fixed; protect the vegetation corridors (herbaceous, shrub and arboreal) with a minimum breadth of 25$100 \mathrm{~m}$ on one and the other sides of the streams and rivers, vegetal detritus is needed to provide the breeding habitat characteristics; forbid the illegal waste depositation of any type in the streams and river and in their sourroundings; avoid sediment extractions or disruption by any way of the riverbed, especially of small lotic systems, keep up of a minimum distance of five $\mathrm{km}$ from every river bed sediment extraction point to the next one; and the design and use of integrated monitoring systems containing ichtyofauna elements.

\section{Site adapted management model}

The basic process for the model of on site management is based on activities (squares), decisions (triangles) and subprocesses (figs. 4-7) in a certain hierarchy (Fig. 3).

Below are the extracted and explained key objects of ADONIS:CE: process ( $(\Delta)$ is any sequence of steps that is initiated by an event; transforms information or materials; activity ( $\square$ ) is used to graphically describe which tasks are executed within a process; decision rule $(\diamond)$ alters a process sequence which are captured and depicted through logical operators, objects, or connectors as is appropriate to the notation used (transition condition and probability are documented for each branch of the process); variables ( $\bullet$ ) will be assigned with values in ADONIS process models through assignment objects and will be queried during the process; random generator (ㄷ) sets a value to a variable to which it is connected; the ability to use subprocesses $(\Delta)$ can be useful as it provides the ability to drill down to the core level and get a more granular view of a process, (Hall and Harmon, 2005). 


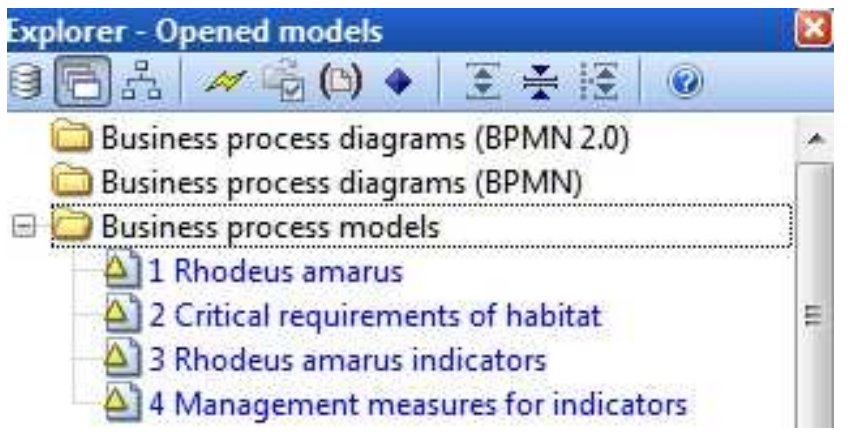

Figure 2. Processes designed for this study on site management model.

Starting from the basic process 1 Rhodeus amarus, figure 3 represents how the subprocesses are called:

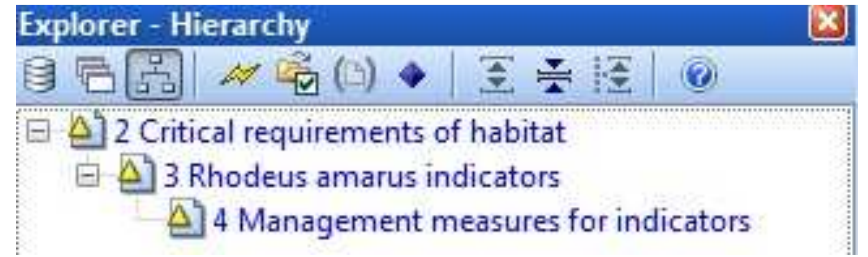

Figure 3. Hierarchy view of modeled subprocesses.

Main modelled process is 1 Rhodeus amarus and shows the ecological requirements of the species sheet (conditions which ensure favourable conservation status). The process was conducted using activities that give details about the species Rhodeus amarus - such as: the scientific name, common names, other ecological requirements (which is the period of reproduction), distribution in the protected area, describing the pressures and threats on the species - and a subprocess which is called in this process and indicates critical habitat requirements.

\section{In process 1 Rhodeus amarus Powered by ADONIS:Community Edition 07.05.2016, 13:38:47}

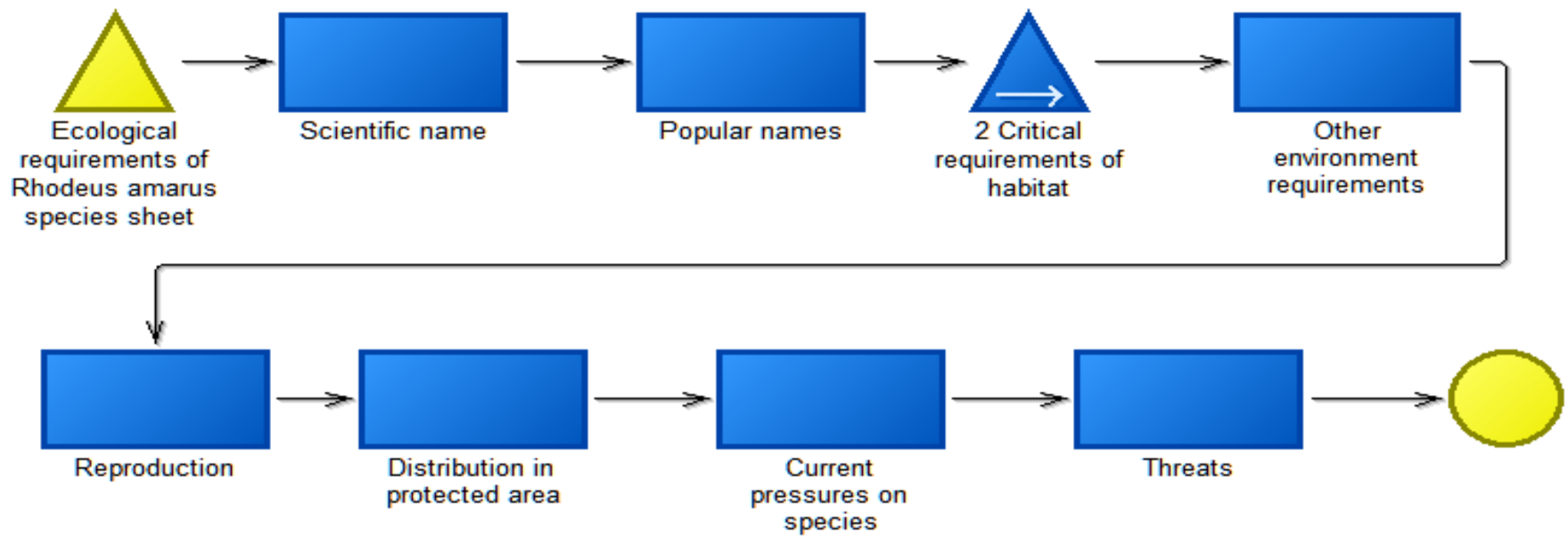

Edit the model attributes to display your copyright info Powered by ADONIS:Community Edition www.adonis-community.com

Figure 4. 1 Rhodeus amarus - main process modelled.

The subprocess was modelled further through 2 Critical requirements of habitat, which is made via four activities (which shows the type of habitat, specific requirements for habitat what species need for breeding, shelter and food - a presentation of the current state versus favourable conservation state indicators - measurements taken on the ground, and other observations from the field), a subprocess which shows all the possible indicators and a decision that verifies if the conditions of conservation of the species are fulfilled. If habitat conditions ensure favourable conservation state (decision: "The conservation state is favourable?" "Conservation_state = 'YES', $75 \%$ probability,") then the process ends with the last activity, namely the presentation of other field observations. If the habitat does not ensure favourable conservation conditions (Decision: "The conservation state is favourable?" "Conservation_state = 'NO', 25\% probability"), then retrieving the subprocess, 3 Rhodeus amarus indicators to obtain a favourable conservation status. 


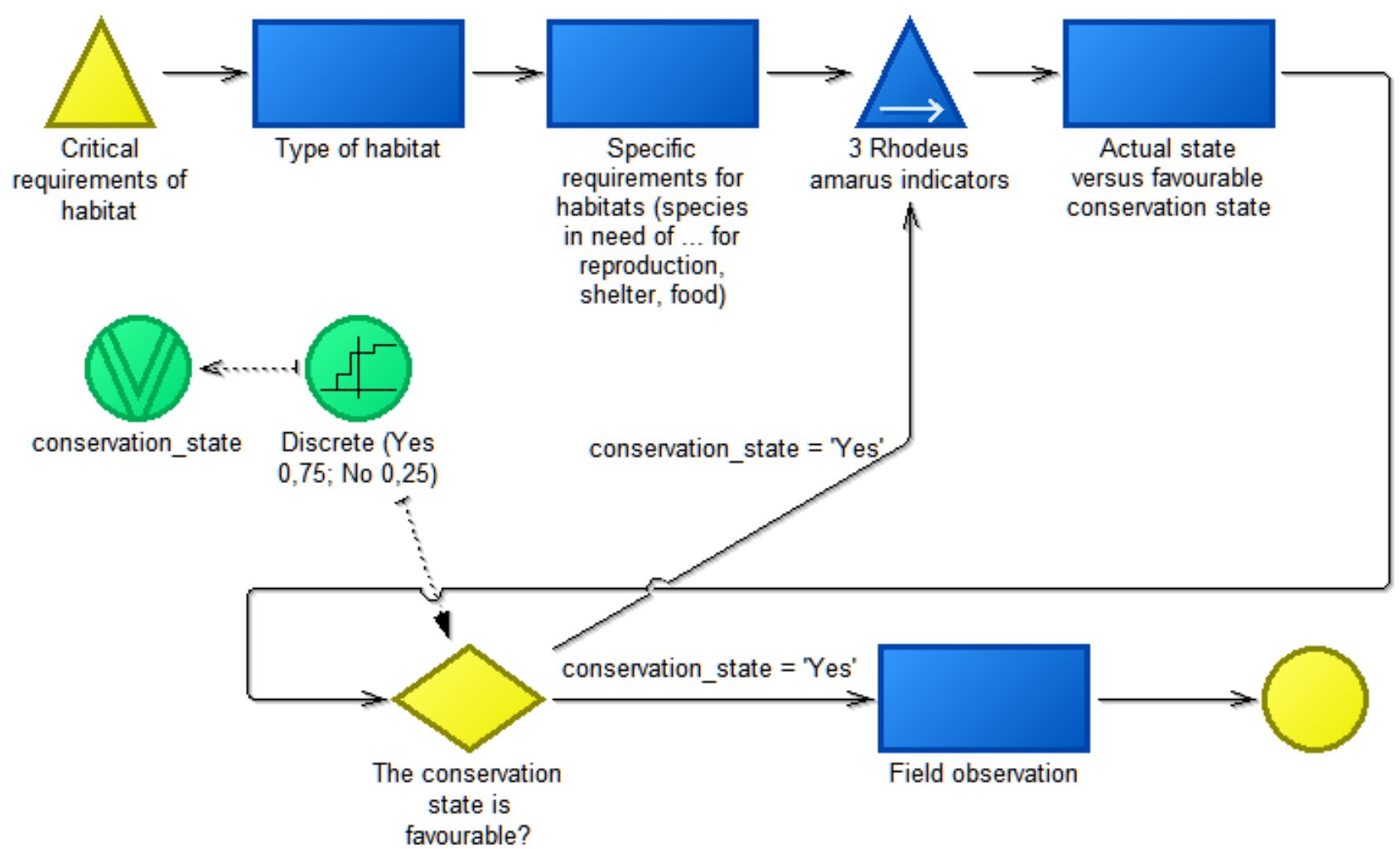

Edit the model attributes to display your copyright info Powered by ADONIS:Community Edition www.adonis-community.com

Figure 5. Subprocess 2 Critical requirements of habitat.

The subprocess, 3 Rhodeus amarus indicators, check all possible indicators to see if they do or do not fulfil favourable conservation statuses. The indicators analyzed are: riverbed areas weight with water depth less than $0.5 \mathrm{~m}$, muddy substrates weight, presence of dead weight arms and wetlands adjacent to watercourses, plant debris on the substrate weight/channel, and slow flow water surface weight. By using decisions, their current and favourable conservation statuses are checked.

E.g.: for muddy substrate weight indicators, favourable conservation statuses should amount to $66 \%$ and the current state is only $33 \%$ of measurements taken on the ground. In this case, management can induce a value of $66 \%$. Management measures are presented in subprocess 4 Management measures for indicators. Decision: "The actual state for muddy substrate weight is $66 \%$ ?", if you go on with "Yes" branch (variable: "muddy_substrate", probability $=50 \%$ ), then you should verify the next indicator. If you go on "No" branch (variable: "muddy_substrate", probability $=50 \%$ ), you should call the subprocess 4 Management measures for indicators. After you called the subprocess then the next four activities should be taken into account: pollution control; rivers of interest on all sectors linked to poaching crimes is very intense; during breeding (April-August) it is recommended to prohibit fishing; implementation of an integrated monitoring system for ichtyofauna conducted by those that are qualified/specialized.
These steps contribute to the preservation of the species and the process then ends. The last subprocess modelled is 4 Management measures for indicators and shows the use of multiple activities that are connected to the management measures taken to ensure favourable conservation status and the process then ends. It brings together all management measures for all indicators. The management measures are: Protection of dead arms and wetlands adjacent to watercourses, maintaining the liquid flow, the current drain regime and a good oxygenation regime of the water, avoiding the increased amount of sediment substances in the water (necessary in terms of protection of essential shellfish habitats for the propagation of Rhodeus amarus species), maintaining the natural morphodynamics minor bed - meanders presence (important for molluscs living in the river bends where sediment such as sand and silt are more stable for important shellfish species for breeding of Rhodeus amarus species), keeping corridors of natural vegetation (arboreal, shrub and herbaceous) with a minimum width of 25$100 \mathrm{~m}$ on both sides of the river in order to ensure the necessary plant debris, prohibit the abandonment of any kind of waste in the riverbed and wetlands surrounding watercourses, and avoidance of extracting sediment or disturbance by other means of substrate structure minor bed of small watercourses with a minimum separation of $5 \mathrm{~km}$ between the mining of aggregate of large riverbeds. 


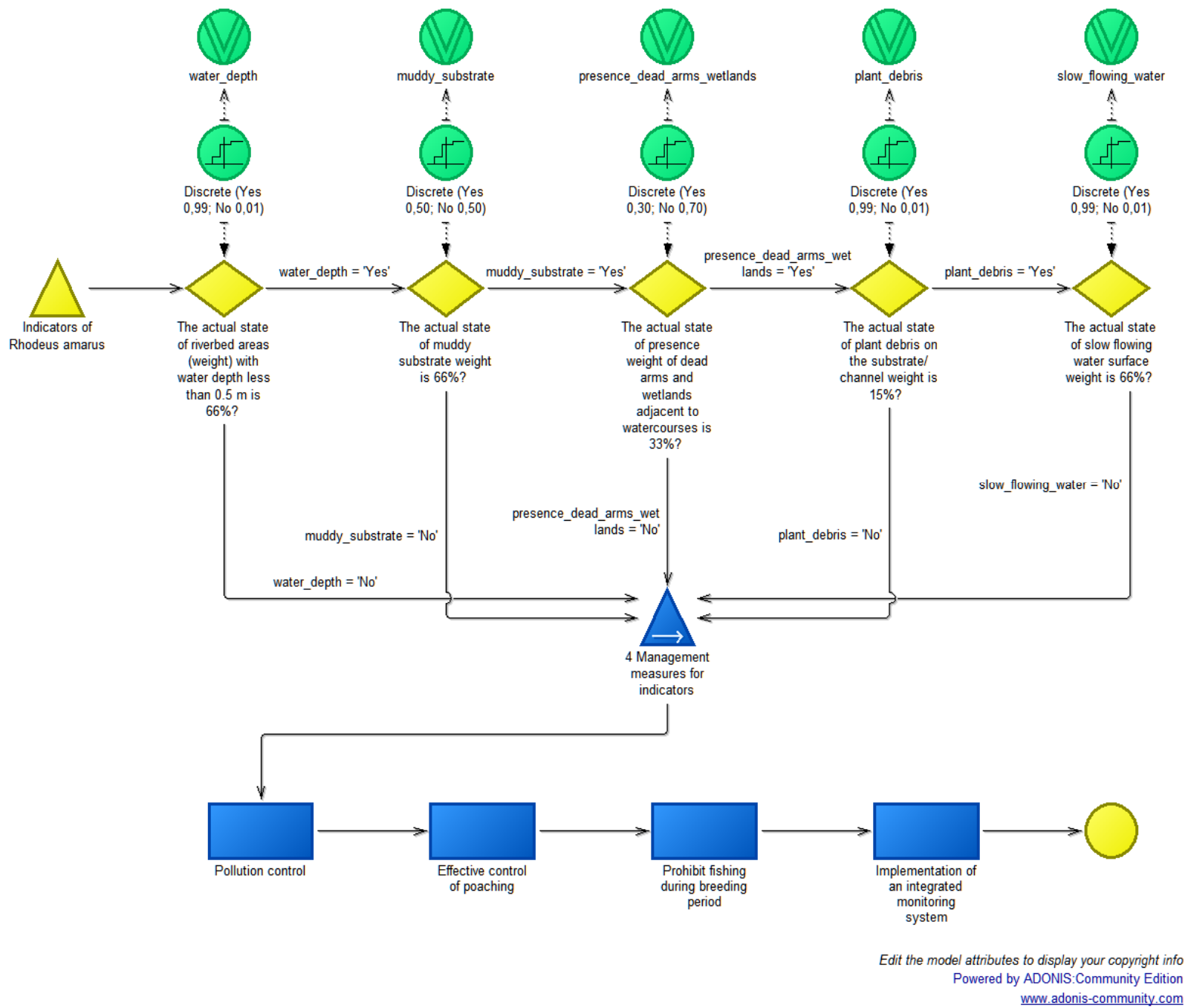

Figure 6. Subprocess 3 Rhodeus amarus indicators.
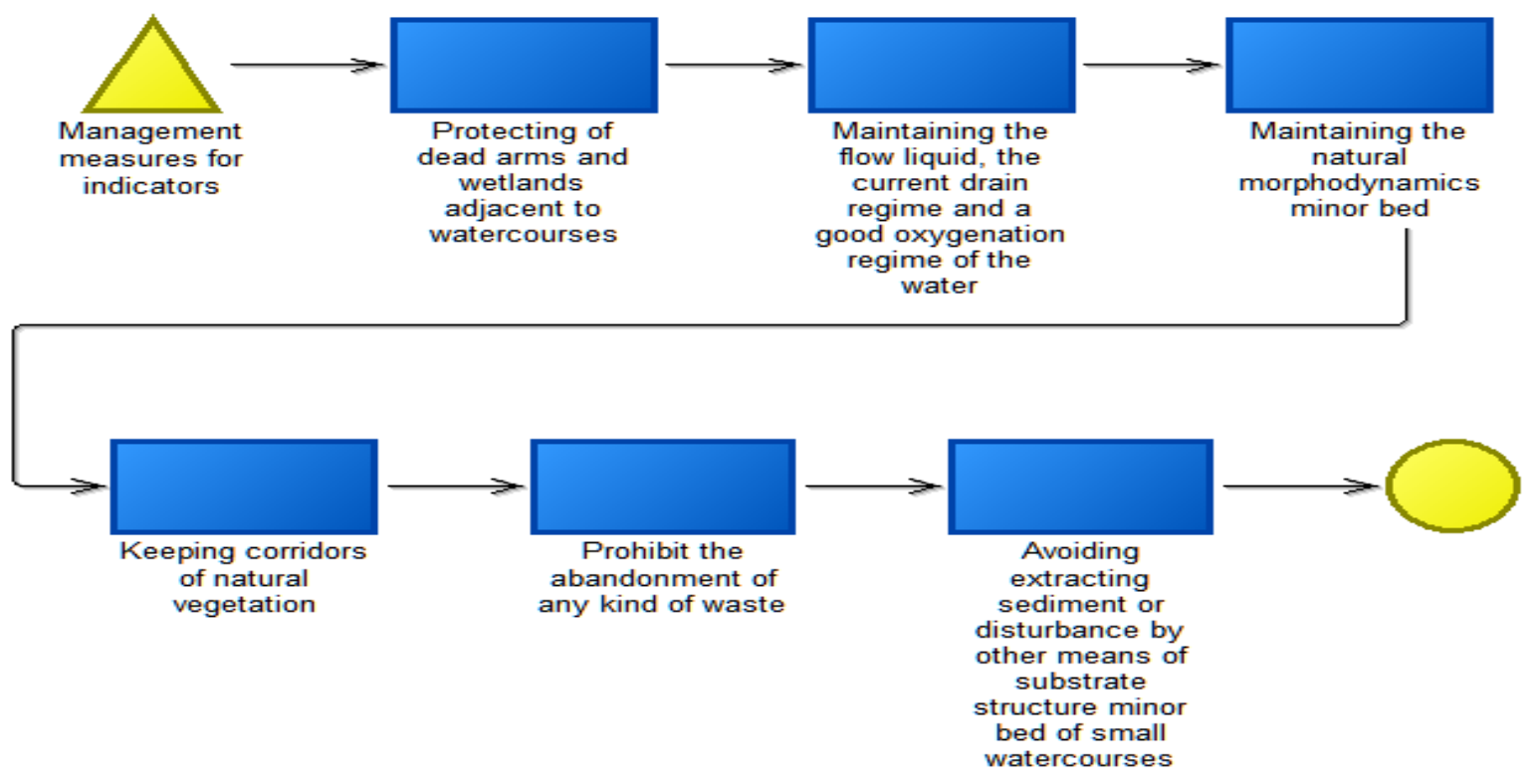

Edit the model attributes to display your copyright info Powered by ADONIS:Community Edition wrw.adonis-community.com

Figure 7. Subprocess 4 Management measures for indicators. 


\section{CONCLUSIONS}

The present principle threat to the Bitterling populations in the Natura 2000 Site, Sighişoara-Târnava Mare, are the hydrotechnical modifications of the river channels, which drive changes in the ecological state of Bitterling populations, and likewise of Unio and Anodonta molluscs. Together with this threat, it should be viewed as equivalent to both chemical pollution and poaching.

All the studied lotic systems should be handled accordingly with the main task of preserving or inducing a needed acceptable chemical quality of the water.

The preserving or re-establishing of the minor riverbeds' natural morphodynamics is significant - the meanders preservation is needed for the aquatic mollusc species which are present mostly in the inner $U$ shape sectors of the lotic systems. The sites, where the sand and mud are relatively fixed, offer proper habitats for the mollusc species significant for the reproduction of Bitterling.

The preservation or improving of the present regimes of oxygenation and liquid flows, and the prevention of the boost in the rate of sediments' deposition in the riverbed are needed also for the molluscs' existence preservation.

The industrial exploitation of sediments in these lotic systems should be realised in relation with their natural rate of redeposition and at places at a distance of more than five $\mathrm{km}$ from each other.

In this study, the "big picture" of the Bitterling was given. ADONIS: CE was applied in this case in an ecology/biology sphere of activity, and we obtained a Bitterling species populations model with all habitat species' necessities, with specific indicators that offer a good preservation status, with the present pressures and threats.

For additional approaches, management systems for more fish species of conservative value of Sighişoara-Târnava Mare Natura 2000 site should be designed.

\section{AKNOWLEDGEMENTS}

The studied data were partially acquired in the EU Structural Operational Programme Environment "Pentru Natură şi Comunităţile locale - Bazele unui management integrat Natura 2000 în zona Hârtibaciu-Târnava Mare-OLT" code SMIS CSNR 17049 .

\section{REFERENCES}

1. Aldridge, D.C., (1999) Development of European bitterling in the gills of freshwater mussels. Journal of Fish Biology, 54: 138-151.

2. Ardelean, G. and Wilhelm, S. (2007) Polluting factors and their effects of the ichthyofauna of the Lăpuș Valley (Maramureș, Romania). Acta Ichtiologica Romanica, II: 17-24.

3. Battes, K.W., Pricope, F., Ureche, D. and Stoica I., (2009) Ichthyofauna status from the Suceava catchment area from 2001 to 2005, Studii şi cercetări Ştiinţifice, Biologie, Seria biologie animală, 17: 59-67.

4. Battes, K.W., Pricope, F., Ureche, D., Stoica, I., (2005) Ichthyofauna status in the Siret catchement area, with emphasis on the effect of the January 2001 pollution, Analele Ştiinţifice ale Univ. „Al. I. Cuza”, Iaşi, secţiunea I Biologie animală, Tom LI, 2005, Ed. Univ. „Al. I. Cuza” Iaşi, 123-143.
5. Battes, K.W., Pricope, F., Ureche, D. and Stoica I., Palaghiţă, D., (2003) Prospective monitoring on fish communities from the Bîrlad catchement area, Universitatea din Bacău, Studii şi Cercetări Ştiinţifice, Biologie, Serie nouă, 8: 102-108.

6. Bănăduc D., (1999) Data concerning the human impact on the ichthyofauna of the upper and middle sectors of the Olt River, Transylvanian Review of Systematical and Ecological Research, 1, Editura Universităţii "Lucian Blaga" din Sibiu, ISSN 1841-7051, ISBN 973-9410-69-3, 157-164.

7. Bănăduc, D., (2000) Ichthyofaunistic criteria for Cibin River human impact assesment, Travaux du Museum National d Histoire naturelle Grogore Antipa, București, XLII: 365-372.

8. Bănăduc, D. (2001) Specii de peşti dulcicoli şi migratori în mediul dulcicol, de interes comunitar, prezente în România, în Natura 2000 în România. Conservarea speciilor şi habitatelor acvatice, coordonator Curtean-Bănăduc Angela, Editura Alma Mater Sibiu, ISBN 973-632-243-2, 72-81.

9. Bănăduc, D. (2005) Fish associations - habitats quality relation in the Târnave rivers (Transylvania, Romania) ecological assessment, Transylv. Rev. Syst. Ecol. Res. 2, (2005), "The Târnava River Basin", 123-136.

10. Bănăduc, D. (2007a) Fish of Natura 2000 network interest in Romania, în Romanian NATURA 2000 NGO Coalition contribution for the SCIs designation, editori Curtean Bănăduc Angela, Florescu Florentina, Editura Alma Mater Sibiu, ISBN 978-973-632-402-4.

11. Bănăduc, D., (2007b) Middle Olt River (Transylvania, Romania) - Special area for conservation (Natura 2000 Site) proposal for Barbus meridionalis Risso, 1827 and associated fish species, Acta Ichtiologica Romanica, II: 3742.

12. Bănăduc, D. (2008a) Natura 2000 sites proposals regarding the fish species of Community interest in the Romanian Alpine Biogeographical Regon, Transylvanian Review of Systematical and Ecological Research, 6, Editura Universităţii "Lucian Blaga" din Sibiu, ISSN 1841-7051, 185-196.

13. Bănăduc, D. (2008b) Natura 2000 sites proposals regarding the Europen Community interest fish (Cyclostomata) species (Romania), Acta Oecologica Carpatica, I: 83-88.

14. Bănăduc, D. (2010), New SCIS proposal regarding the ichthyofauna after the Pannonian Biogeographic Seminar for Romania, Sibiu (Transylvania, Romania) 9-12 June 2008, Acta Oecologica Carpatica, III: 117-122.

15. Bănăduc, D. (2011) New SCIS proposal regarding the ichtiofauna after the Alpine Biogeographic Seminar for Romania, Sibiu (Transylvania, Romania) 9-12 June 2008, Acta Oecologica Carpatica, p. 199-208, IV: 2011.

16. Bănăduc, D., Nagy A., and Curtean-Bănăduc A. (2012) New SCIS proposal regarding the ichtiofauna after the Continental Biogeographic Seminar for Romania, Sibiu (Transylvania, Romania) 9-12 June 2008, Acta Oecologica Carpatica, V: 145-158.

17. Bănăduc, D. and Curtean-Bănăduc, A., (2013) - New SCIs proposal regarding the ichthiofauna for the Stepic Biogeographic area in Romania, Acta Oecologica Carpatica, VI: 137-148.

18. Bănăduc, D., Stroilă, V. and Curtean-Bănăduc, A., 2013 The fish fauna of the Timiş River (Banat, Romania), Transylvanian Review of Systematical and Ecological Research, 15: 145-172. 
19. Bănărescu, P. M., (1964) Pisces-Osteichthyes, Fauna R. P. R., vol. XIII., Edit. Academiei R. P. R., Bucureşti, 962.

20. Bănărescu, P. M. and Bănăduc, D, (2007), Habitats Directive (92/43/EEC) fish species (Osteichthyes) on the Romanian Territory, Acta Ichtiologica Romanica, II: 43-78.

21. Costiniuc, C. D., Davideanu, G. and Davideanu, A. (2006a) Data concerning the fish communities of the Jijia River (Romania), Acta Ichtiologica Romanica, I: 55-64.

22. Costiniuc, C. D., Davideanu, G. and Davideanu, A., (2006b) Some data concerning the fish communities of the Bahlui River (Romania), Acta Ichtiologica Romanica, I: 65-74.

23. Costiniuc, C. D. and Gorgan, L. D., (2004) Researches about Tansa-Belcești lake's ihtiofauna, Analele Ştiinţifice ale Univ. „Al. I. Cuza”, Iaşi, secţiunea I Biologie animală, Tom L, 2004, Ed. Univ. „Al. I. Cuza” Iaşi, 215-221.

24. Curtean, A., Sîrbu, I., Drăgulescu, C., Bănăduc, D., (1999) Impactul antropic asupra biodiversităţii zonelor umede din bazinul superior şi mijlociu al Oltului, Editura Universităţii "Lucian Blaga" din Sibiu, ISBN 973- 651-003-4, 10.

25. Curtean-Bănăduc, A., Bănăduc, D. (2012) Aspecte privind impactul deversării apelor uzate asupra sistemelor ecologice lotice receptoare, în Apa resursă fundamentală a dezvoltării durabile. Metode şi tehnici neconvenţionale de epurare şi tratare a apei, Vol. II, coordonator Oprean L., Editura Academiei Române, 393 - 416.

26. Curtean-Bănăduc A., Bănăduc D., Bucşa C. (2007) Watershed Management (Transylvania, Romania) implications, risks, solutions, Strategies to Enhance Environmental Security in Transition Countries, NATO Security trough Science Series - C: Environmental Security, Springer, 225 - 238, ISBN 978-1-4020-5995-7.

27. Curtean-Bănăduc A., Bănăduc D. (2001) Cibin River (Transylvania, Romania) management, scientific foundation proposal, Acta oecologica, Vol. VIII, Nr. 1-2, Editura Universităţii "Lucian Blaga" din Sibiu, ISSN 1221$5015,85-100$.

28. Curtean-Bănăduc A., Bănăduc D. (2004a) Cibin River fish communities structural and functional aspects, Studii şi Cercetări Ştiinţifice - Seria Biologie, Universitatea din Bacău, vol. 9, ISSN 122-919-X, 93 - 102.

29. Curtean-Bănăduc, A., Bănăduc D. (2004b) Aspecte privind dinamica faunei râului Cibin în ultimii 150 de ani, Studii şi Comunicări, Muzeul Brukenthal Sibiu, Ştiinţele Naturii, vol. 29, ISSN 1454-4784, 205 - 214.

30. Curtean-Bănăduc, A., Bănăduc, D. (2008) Natura 2000 sites proposals regardingthe fish species $f$ Community interest in the Romanian Panonian Biogeographical Region, Acta oecologica cibiniensis, Vol. I, Editura Universităţii "Lucian Blaga" din Sibiu, ISSN 1221-5015, 75 -95 .

31. Florea, L. Contoman, M., (2014a) Speciile de pești de interes comunitar din fluviul Dunărea, Volumul Simpozionului Internaţional „Sustainable use and protection of animal world diversity", Chisinau, 30-31 oct. 2014, ISBN 978-9975-62-379-7, 2007-2009

32. Florea, L. Contoman M., (2014b) Inventarierea Peștilor din Parcul Natural Balta Mică a Brăilei, Volumul Simpozionului Internaţional „Sustainable use and protection of animal world diversity", Chisinau, 30-31 oct. 2014, ISBN 978-9975-62-379-7, 2009-2011.

33. Hall, C., Harmon, P., (2005) The Enterprise Architecture, Process Modeling \& Simulation Tools Report, Version 1.1 (2005) November, 2005, http://mhcnet.com/whitepapers_presentations/2005 Process Trends (040306).pdf)
34. Holcik, J., (1999). Rhodeus sericeus (Pallas, 1776). In Bănărescu, P. M. (Ed.), The Freshwater Fishes of Europe, Vol. 5/1, Cyprinidae 2/1. AULA-Verlag, Wiebelsheim, 132.

35. Meșter, L., Crăciun, N., Aioanei, F., Ureche, D. (2003) Research on the fish fauna in the Argeş, Neajlov, Sabar, Ialomiţa, Dâmboviţa and Colentina River Basins, Universitatea din Bacău, Studii şi Cercetări Ştiinţifice, Biologie, Serie nouă, 8: 140-153.

36. Momeu, L, Battes, K., Battes, K., Stoica, I., Avram, A., Cîmpean, M., Pricope, F, and Ureche, D., (2009) Algae, macroinvertebrate and fish communities from the Arieș River Catchment area (Transylvania, Romania), Transylv. Rev. Syst. Ecol. Res. 7, "The Arieş River Basin", 151-182.

37. Năstase, A., Năvodaru, I. Cernișencu, I., 2008 Comparative data of ichthyodiversity from SomovaParcheș complex lakes (Romania), Acta Ichtiologica Romanica, III: 93-104.

38. Năvodaru, I. and Năstase, A., (2006) Ichthyofauna of River Danube Delta: Gorgova - Uzlina and Şontea - Furtuna lakes complexes, Acta Ichtiologica Romanica, I: 185-202.

39. Năvodaru I., (2004) Possibilities of ecological and ichthyofaunistic reestablishments of the former easily flooded region of the Danube - the Călărași Island - Bala, Studia Univ. Vasile Goldiș, Seria Șt. Vieții, 14: 93-99.

40. Oţel V., (2007) The present status of the fish species considered of community and national interest, in the Danube delta Biosphere Reserve, Romanian sector, Acta Ichtiologica Romanica, II: 177-188.

41. Pintilieasa R., Ureche D., Ureche C. (2011) Status of the fish communities in the upper basin of River Mureș in 2009, Studii şi cercetări știinţifice, Biologie, Seria biologie animală, 20 (2): 158-165.

42. Pricope, F., Battes, K. W., Ureche, D., (2001) Monitorizarea ihtiofaunei din bazinul superior al râului Suceava şi Moldova, Buletin Ştiinţific, Seria B, Vol. XIV, Fasc. Chimie-Biologie, Universitatea de Nord Baia-Mare, 143-150.

43. Radu, G. A., Meliceanu, I. and Patriche, N., 2008 Ichthyofauna, an important heritage of the lower Prut floodplain (Moldova, Romania), Acta Ichtiologica Romanica III: 137-146.

44. Simalcsik, F., Misăilă, E. R., Misăilă C., Pricope F., (2004) The effect of Rivers' pollution with cellulosic and municipal used waters in ichtyofauna's integrity, Studia Univ. Vasile Goldiș, Seria Șt. Vieții, 14: 135-140.

45. Smith, C. M., Reichard, P., Jurajda Przybylski M., (2004) The reproductive ecology of the European bitterling (Rhodeus sericeus). Journal of Zoology, 262: 107-124.

46. Telcean, I., Bănărescu P., (2002) Modifications of the fish fauna in the upper Tisa river and its southern and eastern tributaries, in Tiscia Monograph Series 6 Ecological aspects of the Tisa River Basin (Sarkany A and Hamar J. eds.), 179-186.

47. Telcean, I., (1999) Starea naturală a văilor din bazinul Crişurilor, Fluvii Carpatorum, Sarkany-Kiss E., Sîrbu I., Kalivoda B., eds. Szolnok-Tg. Mureș, 227-233.

48. Telcean, I., (2010) Notă asupra ihtiofaunei canalului colector al Crişurilor şi a bălţilor învecinate, Ocrotirea naturii. Serie nouă, tom 46, 119-123, Ed. Acad. Rom.

49. Telcean, I., Cupşa D., (2009a) The backwaters and drainage canals as natural refuges for the lowland rivers' fishfauna (Someş, Crişuri, Mureş - North-Western Romania) Biharean Biologist Vol. 3, No.1, 37-44. 
50. Telcean, I., Cupşa, D., (2009b) Fishfauna from the lowland Mureş River and the Floodplain Natural Park area (Western-Romania), Analele Universităţii din Oradea, Fascicula de Biologie, Tom XVI, 2009, 132-136.

51. Ureche, D. (2008) Studii ecologice privind ihtiofauna din bazinul mijlociu şi inferior al râului Siret, Editura PIM, Iaşi, 223.

52. Ureche, D., Pintilieasa R., Ureche C., Voicu R. E., (2013). Researches on the fish communities in the middle basin of River Mureș in 2009-2011, Analele Ştiinţifice ale Univ. "Al. I. Cuza" Iaşi, secţiunea I Biologie animală, Supliment 2011, Ed. Univ. "Al. I. Cuza" Iaşi, 127-136.
53. Ureche, D., Ureche C., Nicoară M., Plăvan G., (2010) The role of macroinvertebrates in diets of fish in River Dâmbovița, România, Verh. Internat. Verein. Limnol., 30 (10): 1582-1586.

54. Vornicu B., Davideanu G. and Davideanu A., (2006) Data concerning the fish communities of the Moldova River (Romania), Acta Ichtiologica Romanica, I: 293-304.

55. * (1992) Council Directive 92/43/EEC of 21 May 1992 on the conservation of natural habitats and of wild fauna and flora. http://eur-lex.europa.eu/legal-content/EN/TXT/?uri $=$ CELEX:31992L0043

56. $* *$ http://www.boc-group.com/products/adonis/bpmn- 